\title{
Lack of recovery symptoms of an endangered and harvested mollusc in the last 20 years
}

\author{
RODRIGO RIERA ${ }^{1}$, ROGELIO HERRERA ${ }^{2}$, ÓSCAR PÉREZ ${ }^{1}$, MATEO J. GARRIDO ${ }^{2}$, OMAR ÁLVAREZ ${ }^{1}$, \\ ÓSCAR MONTERROSO ${ }^{1}$ AND JORGE NÚÑ̃̃Z \\ ${ }^{1}$ Centro de Investigaciones Medioambientales del Atlántico, 38107 SC de Tenerife, Canary Islands, Spain, ${ }^{2}$ Viceconsejería de \\ Medioambiente del Gobierno de Canarias, 35071 Las Palmas de Gran Canaria, Canary Islands, Spain, ${ }^{3}$ Benthos Lab, Department of \\ Animal Biology, University of La Laguna, 38206 La Laguna, Canary Islands, Spain
}

\begin{abstract}
Molluscs are subjected to intense harvesting in many areas around the world. Conservation measures have been developed to preserve populations of an overexploited gastropod species, the abalone Haliotis tuberculata coccinea. This species was surveyed in subtidal localities throughout coastal Tenerife, Canary Islands over the last two decades (1994-2014). A clear indicator of non-recovery was observed in the decrease of mean size throughout the last two decades, even after the inclusion of this species in the Regional Catalogue of Endangered Species. The mean size of abalones decreased from $33.5 \mathrm{~mm}$ (1994) to 28-29 $\mathrm{mm}$ (2002 and 2014), corresponding to sub-adult individuals. The structure of size classes was typical of an overexploited species, with reduced occurrence of large individuals $\left(>_{50} \mathrm{~mm}\right.$ ). Several factors might explain this pattern such as illegal harvesting, proliferation of featureless benthos and a decrease of suitable habitats for colonization and settlement. Complementary conservation actions are urgently needed to preserve this species in the area studied.
\end{abstract}

Keywords: Harvesting, subtidal, molluscs, abalones, Canary Islands, Atlantic Ocean

Submitted 17 June 2015; accepted 9 September 2016; first published online 17 October 2016

\section{INTRDDUCTION}

Mollusc and crab harvesting has received comparatively less attention than effects of fish harvesting on coastal biodiversity (Smil, 2012). The effects of mollusc harvesting in coastal ecosystems have been scarcely considered until now (e.g. Beck et al., 2011) and mollusc harvesting also has consequences for other species, such as predators, competitors, algae and parasites (Coleman et al., 2006). The consequences are worldwide since a wide range of molluscs have been extensively harvested around the globe in intertidal and shallow subtidal areas, including clams, mussels, octopuses, squids, limpets and abalones (Hackney \& Rippen, 2000).

Abalones (Haliotis spp.) have been traditionally harvested in many coastal areas worldwide, e.g. Australia, New Zealand, Chile, South Africa and California, because of their commercial value (Leiva \& Castilla, 2001; Maynard et al., 2004; Li et al., 2006). In recent decades, due to increasing harvesting effort the abalone stocks have dramatically decreased (Guzmán del Próo, 1992; Morales-Bojórquez et al., 2008), even to unsustainable levels underpinning that several species are currently of concern (Kashiwada \& Taniguchi, 2007; Micheli et al., 2008). In Europe, the species Haliotis tuberculata Linnaeus, 1758 , commonly known as the Ormer, has been traditionally considered a delicacy in the British Channel Islands and the adjacent Atlantic French coast (FAO, 1995). Official bans were imposed in the 1970 s in an attempt to reverse the overexploitation of this mollusc

Corresponding author:

R. Riera

Email: rodrigo@cimacanarias.com
(Berthou et al., 1985). This species, as in all haliotids, has a short pelagic-larval dispersive stage before settlement (Courtois de ViÇose et al., 2007) and as a result their populations are highly patched (McShane, 1996). Such reproductive behaviour may have implications on isolated populations, with limited or no connectivity with other abalone populations, for example in oceanic islands such as the Canary Islands.

A subspecies of the ormer (H. tuberculata coccinea Reeve, 1846) has been harvested in the Canary Islands since aboriginal times, because of its ready accessibility, high protein content and agreeable flavour (Nuñez et al., 1994). This situation also creates a high pressure on larger individuals, resulting in profound shifts in size classes of populations, with a lower representation of adult specimens $(>35 \mathrm{~mm}$ shell size), together with a sharp reduction in abundances (Espino \& Herrera, 2002). For these reasons, this subspecies was classified as an endangered species in the Catalogue of Threatened Species of the Canary Islands (BOC, 2001). This inclusion resulted in the closure of the abalone fishery in the whole archipelago. Unfortunately, no available information exists about the current state of conservation of this species, nor the effects of natural and anthropogenic stressors on size structure of populations throughout recent decades.

The main aim of the present study was to explore temporal size variations of Haliotis tuberculata coccinea individuals over the last 20 years $(1994-2014)$ in Tenerife, one of the islands of the Canarian archipelago. We hypothesized that the mean size has decreased in more recent years due to several factors, such as harvesting, regardless of its inclusion as endangered species in the regional catalogue. Thus, we use size as a surrogate of the population status of this locally endangered gastropod. 


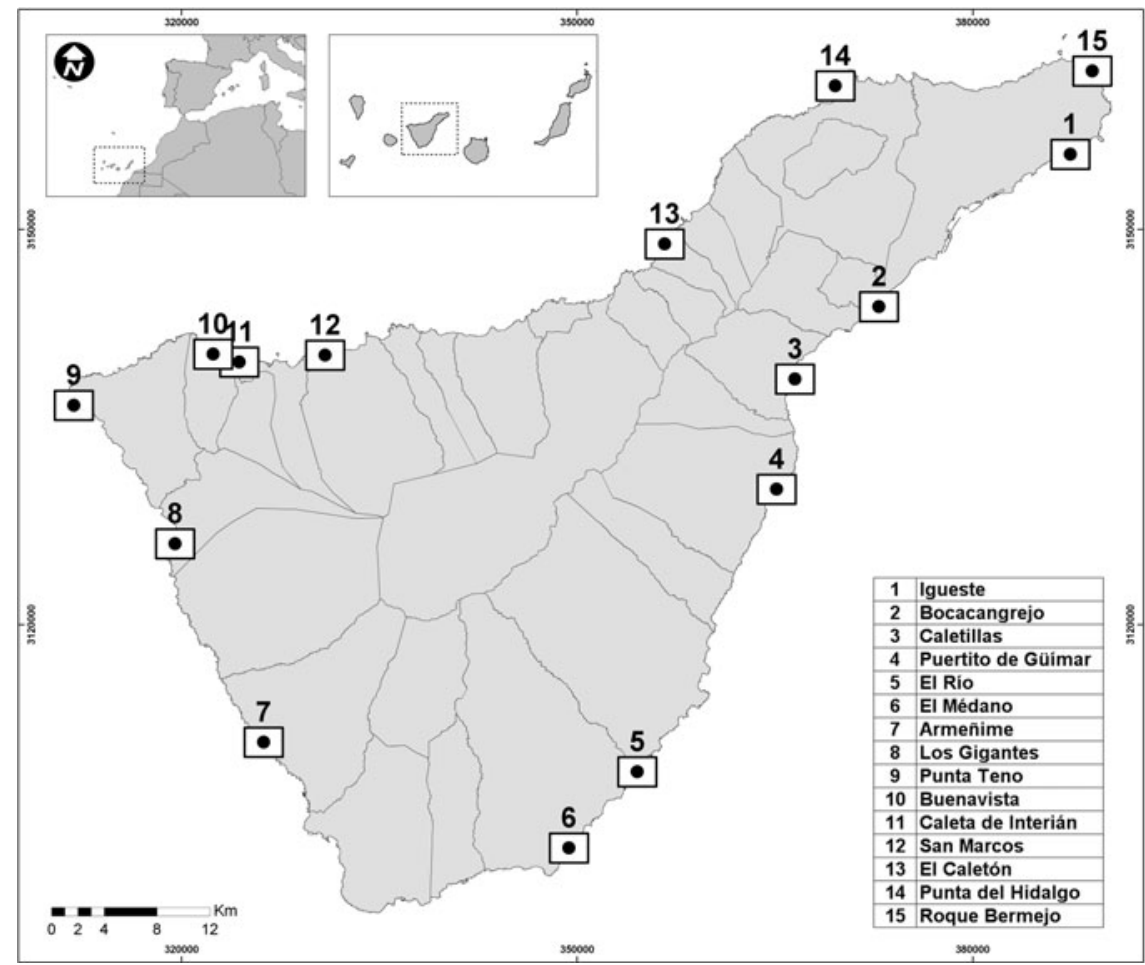

Fig. 1. Map of Tenerife (Canary Islands) showing sampling locations.

\section{MATERIALS AND METHDDS}

This study was conducted at subtidal locations in Tenerife, the most populated island in the Canarian archipelago. A total of 15 locations (Armeñime, Bocacangrejo, Buenavista, Caleta de Interian, Caletillas, El Caleton, El Rio, Igueste, Los Gigantes, Medano, Puertito de Güímar, Punta del Hidalgo, Punta de Teno, Roque Bermejo and San Marcos) were sampled, corresponding to coastal towns throughout Tenerife (Figure 1). At each site, all abalones (Haliotis tuberculata coccinea) were recorded during $30 \mathrm{~min}$ of surveying by scuba. A minimum of three replicates were sampled at each locality. The sampling effort varied among field surveys (1994, 2002 and 2014), with different number of replicates within the same coastal location. Therefore, abalone abundance data were not utilized for comparative analysis. Each abalone was measured across the widest part of the shell to the nearest millimetre using calipers.

The shell size of Haliotis tuberculata coccinea is a surrogate of reproductive potential (Nuñez et al., 1994). The size of first maturity of this species is $30 \mathrm{~mm}$, and $>35 \mathrm{~mm}$ individuals are considered adults. Large-sized individuals $\left(>_{50} \mathrm{~mm}\right)$ harbour the highest reproductive potential because fecundity increases exponentially with size (Nuñez et al., 1994).

The depth range of this species varied from the intertidal to $15 \mathrm{~m}$ depth, however, currently, $H$. tuberculata coccinea individuals are restricted to the shallow subtidal ( $1-6 \mathrm{~m}$ depth) because of the increase in barren areas of seabed in the Canaries (Espino \& Herrera, 2002). This increase is underpinned by the high densities of the sea urchin Diadema africanum. The target species lives underneath stones and shows affinity for exposed and semi-exposed areas with round stones covered by coralline red algae that constitute its main food source (Espino \& Herrera, 2002).
A comparative study, using individual sizes, was conducted using the current data collected in 2014 and previous data from 1994 (Nuñez et al., 1994) and 2002 (Espino \& Herrera 2002). Spatial variability was also considered, grouping sampling locations together depending on their shore orientation and thus accessibility to the coast (North $(<100$ days accessible), East $(200-250$ days accessible) and Western $(>300$ days accessible)).

A multivariate comparison of the sizes of abalones was conducted using an analysis of variance (ANOVA). Despite the heterogeneity of the variances (Levene's test), the increase of type I error was avoided by reducing the $P$ value to 0.01 level (Underwood, 1991). The factors 'Time' and 'Orientation' were included in the comparative study (1994-2002-2014). The Scheffé test was used for post-hoc procedures. All multivariate procedures were carried out using the SPSS 17.0 statistical package.

\section{RESULTS}

The mean individual size of abalones considering all surveys (1994, 2002 and 2014) is $28.85 \pm 9.67 \mathrm{~mm}$, typical of a nonadult specimen $(<35 \mathrm{~mm})$. Consistent differences were observed in size of individuals between 1994 and the remaining field surveys (2002 and 2014) (one-way ANOVA, $F=17.535, P$ $<<0.0001$ ) (Table 1). Post-hoc tests did not show differences between the sizes of individuals surveyed in 2002 and 2014 (Table 1). The mean individual size in 1994 was $33.51 \pm$ $12.39 \mathrm{~mm} ;<_{30} \mathrm{~mm}$ in $2002(28.07 \pm 9.21 \mathrm{~mm})$ and 2014 $(29.14 \pm 8.41 \mathrm{~mm})$ (Figure 2). However, the most abundant size class in 1994 was $21-25 \mathrm{~mm}(16.8 \%)$ whilst in 2002 was $31-35 \mathrm{~mm}(21.8 \%)$ and $26-30 \mathrm{~mm}(23 \%)$ in 2014.

Large-sized individuals $(>50 \mathrm{~mm})$ were rather scarce in all field surveys, ranging from $2.1 \%$ in 1994 to $0.37 \%$ in 
Table 1. Results of ANOVA testing for differences in abalone size throughout the study period ('Time', fixed factor) and at different shore locations ('Orientation', random factor).

\begin{tabular}{lrrrrc}
\hline Factor & df & MS & F & $P$ & $\begin{array}{l}\text { Post-hoc } \\
\text { tests }\end{array}$ \\
\hline Time & 2 & 1415.93 & 15.614 & $<<0.0001$ & $\begin{array}{c}1994>2002, \\
2014\end{array}$ \\
Orientation & 2 & 118.49 & 1.307 & 0.271 & \\
$\begin{array}{l}\text { Orientation(Year) } \\
\text { Residual }\end{array}$ & 8 & 496.28 & 5.491 & $<<0.0001$ & \\
\hline
\end{tabular}

Significant differences $(P<0.01)$ are highlighted in bold.

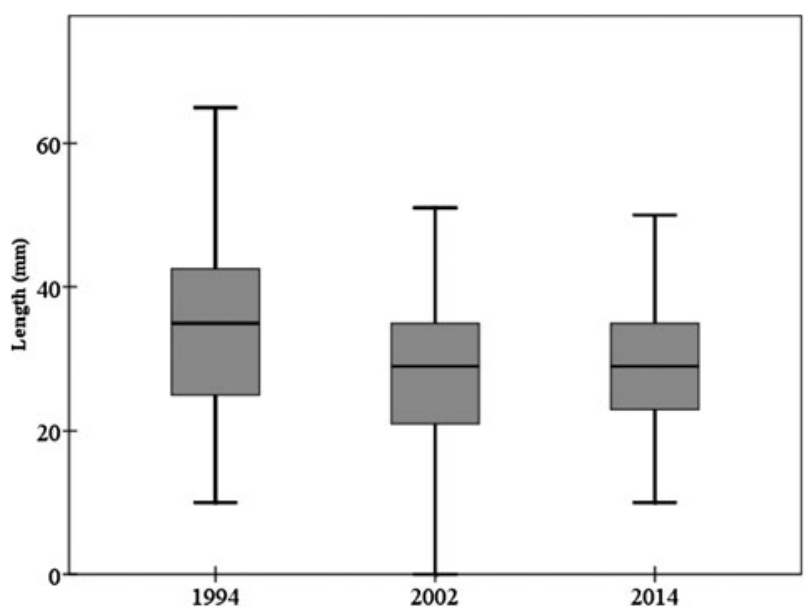

Fig. 2. Mean abalone size throughout the study period considering the three field surveys. Box-plot showing median (black line) and upper and lower data quartiles (box).

2002. The adult individuals with a size $>35 \mathrm{~mm}$ were not the dominant size of the abalone populations in the last two decades, ranging from $27.8 \%$ in 2002 to $38 \%$ in 2014 (Figure 3).
If coastal orientation and accessibility is considered, no significant differences were found between northern, eastern and western abalone populations $(F=1.307, P=0.271)$. However, these differences were consistent across all three field surveys $(1994,2002$ and 2014) $(F=5.491, P<0.0001)$. This variability was mainly explained by the higher sizes of abalones on the eastern (mean: $33 \pm 13 \mathrm{~mm}$ ) and northern (mean: $34 \pm 12 \mathrm{~mm}$ ) coasts of Tenerife in 1994 compared with the individuals surveyed in 2002 and 2014. In 2002 and 2014 no abalone populations in the different coasts of the island were characterized by a $>35 \mathrm{~mm}$ size (adults) or even 'pre-adult' size $(>30 \mathrm{~mm})$, with the exception of western individuals in 2014 (mean: $31.5 \pm 7.6 \mathrm{~mm}$ ) (Figure 4).

\section{DISCUSSIDN}

Temporal trends showed a small, though significant, decrease in size of Haliotis tuberculata coccinea in the last 20 years. From 1994, the shell size of abalones has decreased 4$5 \mathrm{~mm}$, resulting in populations characterized by non-adult mean sizes $(<30 \mathrm{~mm})$. Large-sized individuals, with the highest reproductive potential and the most value for illegal harvesters, were rather scarce $(<2.5 \%)$ in all surveys.

These results are a priori surprising if we consider the inclusion of Haliotis tuberculata coccinea in the Regional Endangered Species Catalogue in 2001. However, several factors are currently affecting the recovery of this species in the Canary Islands, and particularly in Tenerife. Firstly, illegal harvesting still occurs in several areas because of lack of proper enforcement and the high demand on the black market $(>30 € \mathrm{~kg}-$ ). Secondly, the massive proliferation of the sea urchin Diadema africanum has underpinned a dramatic collapse of coastal ecosystem productivity in the Canary Islands (Tuya et al., 2004). This species has completely removed the algae from previously vegetated rocky reefs, resulting in barren seabeds and a depleted food source for

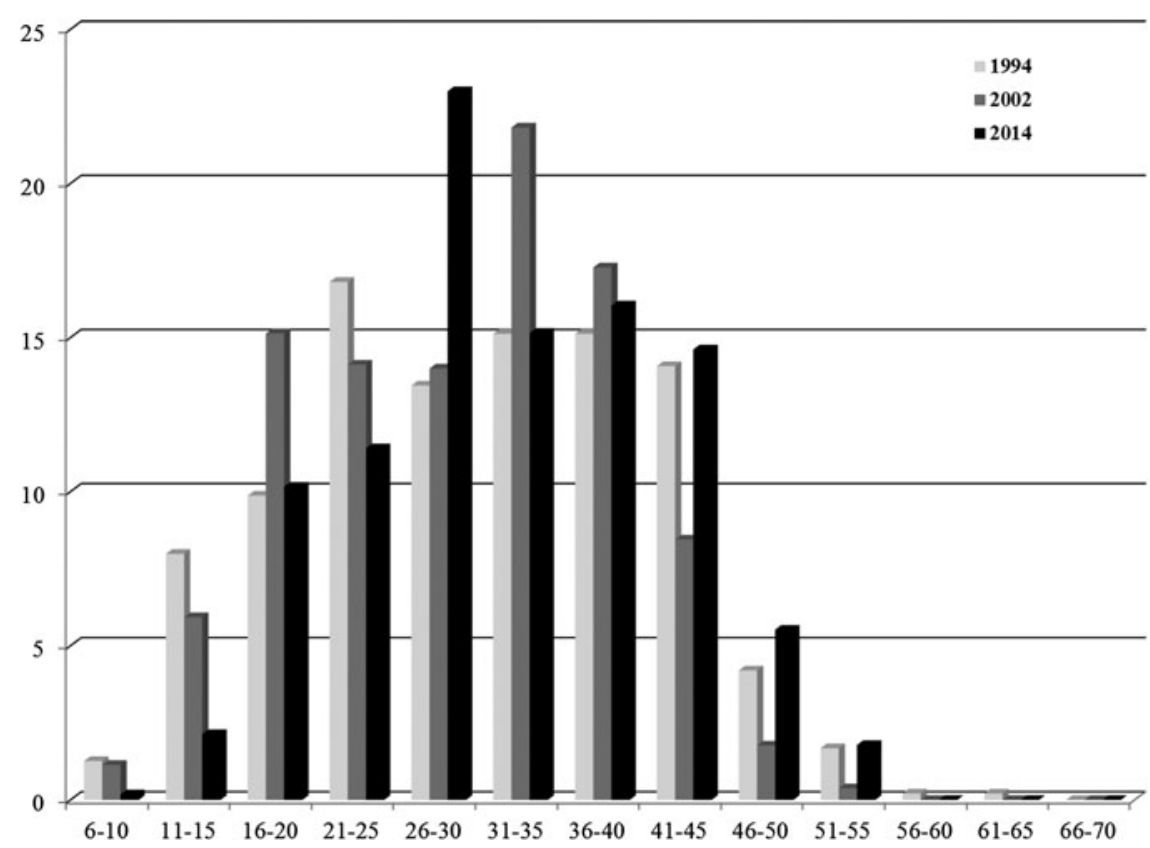

Fig. 3. Size classes of the abalone Haliotis tuberculata coccinea in the three field surveys. 


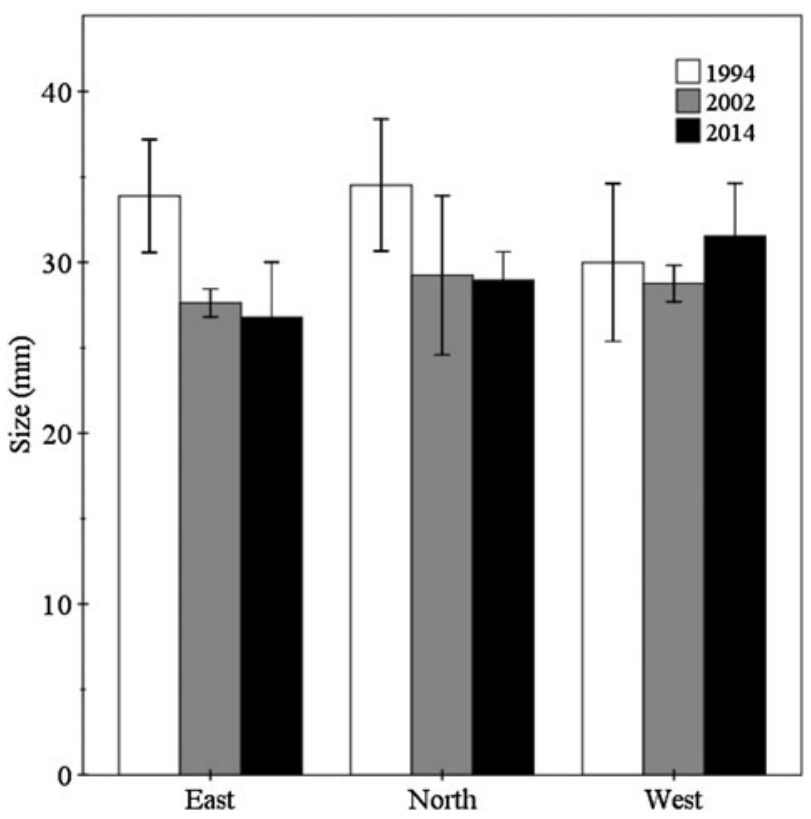

Fig. 4. Mean $( \pm S E)$ size of abalones considering coastal orientation in the field surveys.

abalone. No Haliotis individuals are found underneath stones on barren seabeds (Nuñez et al., 1994). Thus, suitable substrates for the colonization and settlement of abalones are limited to a narrow fringe from the lower intertidal to shallow subtidal (3-6 m deep), inaccessible to D. africanum due to wave exposure (Tuya et al., 2004). Overturning of rocks to collect fishing bait (e.g. crabs) in the intertidal also affects Haliotis populations due to consequential loss of algae on the rocks' surface (Espino \& Herrera, 2002). Another factor not usually considered is the increased sedimentation rate in coastal areas of Tenerife over the last two decades (Herrera \& Riera, personal observation). This clearly reduces the number of suitable habitats for viable Haliotis populations.

Abalone harvesting in Tenerife has been banned since 2003 (fishing regulation no. 17/2003), due to the low abundances and predominance of small-size individuals. Populations of H. tuberculata coccinea probably still only exist in Tenerife because this species is no longer considered a priority-target for illegal harvesters over the last few years following the ban. Currently, other molluscs, such as limpets are the main priority for harvesters in the Canarian archipelago (Riera et al., 2016).

Abalones have been overexploited in several areas worldwide (e.g. Leiva \& Castilla, 2001; Micheli et al., 2008; Morales-Bojórquez et al., 2008). A series of conservation actions have been developed to preserve populations, however, stocks of abalones have not experienced a substantial increase along the California coast (Gruenthal \& Burton, 2005; Kashiwada \& Taniguchi, 2007). Marine protected areas (MPAs) have been shown to be an effective tool to enhance local population recovery of abalones (Micheli et al., 2012). Networks of marine reserves may work more effectively to ensure genetic flow among abalone populations (Rogers-Bennett et al., 2002), though their effects are spatially limited (Micheli et al., 2012).

Current genetic studies indicate that abalone populations are genetically different, e.g. the green abalone (Haliotis fulgens) (Gutierrez-Gonzalez et al., 2007). This phenomenon has profound implications in their conservation, since isolated populations may have higher probabilities to collapse (Miller et al., 2009). A detailed genetic study involving populations of $H$. tuberculata coccinea from several islands of the Canarian archipelago is of utmost importance to establish the first steps of understanding small-scale variability and gene flow rates and patterns. Simultaneously, aquaculture trials with the study species (Haliotis tuberculata coccinea) have been conducted with successful results (Bilbao et al., 2010; Courtois de Viçose et al., 2012). These pilot studies were carried out for two main purposes: (i) production of juveniles for the shellfish market; (ii) restoration of natural coastal populations (Viera et al., 2016). In several geographic areas aquaculture of abalones for the purposes of rearing juveniles for population replenishment may be one of the viable solutions to preserve isolated populations, with no connections with other abalone assemblages (Huchette \& Clavier, 2004; Bilbao et al., 2010).

A network of no-take areas with a high connectivity among them is of utmost importance for the conservation of H. tuberculata coccinea in the Canary Islands and especially in Tenerife. These no-take areas should be accompanied by strict surveillance and enforcement to ensure no illegal harvesting occurs. Two marine protected areas, Anaga (NE of Tenerife) and Teno (NW of Tenerife) will be established in the near future (Pascual-Fernandez et al., 2015). All-year round closed seasons are necessary in these areas in order to preserve pools of individuals in the island with a good representation of large-sized individuals $\left(>_{50} \mathrm{~mm}\right)$. These actions must be implemented urgently, since the present results show the ineffectiveness of current conservation measures and fisheries enforcement in the Canarian archipelago.

\section{ACKNDWLEDGEMENTS}

We are grateful to the staff of CIMA SL for support during the fieldwork and encouragement throughout the study.

\section{FINANCIAL SUPPDRT}

This study was funded by the European fisheries funding 'Axis 4' Sustainable development of Fishing areas', through the Coastal Action Group within the framework of the project 'Management and conservation of coastal shellfish resources in Tenerife' (cod. 411NCANooo44). Fernando Espino and Oscar Tavio are also acknowledged for their support during 2002 field surveys that were funded by the Consejería de Medio Ambiente y Ordenación Territorial (Canarian Government) (SEGA, 2002).

\section{REFERENCES}

Beck M.W., Brumbaugh R.D., Airoldi L., Carranza A., Coen L.D., Crawford C., Defeo O., Edgar G.J., Hancock B., Kay M.C., Lenihan H.S., Luckenbach M.W., Toropova C.L., Zhang G., and Guo X. (2011) Oyster reefs at risk and recommendations for conservation and restoration and management. Bioscience 61, 107-116.

Berthou P., Beurier J.P., Buestel D. and Clavier J. (1985) Etat actuel des connaissances sur les stocks naturels d'ormeaux: elements halieutiques et juridiques. Pêche Maritime 64, 288-294. 
Bilbao A., Tuset V., Viera M., Courtois de Vicose G. Fernandez-Palacios H., Haroun R. and Izquierdo M. (2010) Reproduction, fecundity and growth of abalone (Haliotis turberculata coccinea, Reeve 1846) in the Canary Islands. Journal of Shellfish Research 29, 959-967.

BOC (2001) Official Gazette of the Canary Islands (2001/097) published on August 1, 2001. Royal Decree 151/2001 of 23 July 2001, which approves the Catalogue of Threatened Species of the Canary Islands.

Coleman M.A., Underwood A.J. and Benedetti-Cecchi L., Aberg P., Arenas F., Arrontes J., Castro J., Hartnoll R.G., Jenkins S.R., Paula J., Della-Santina P., and Hawkins S.J. (2006) A continental scale evaluation of the role of limpet grazing on rocky shores. Oecologia 147, 556- 564

Courtois de Viçose G., Viera M.P., Bilbao A., and Izquierdo M.S (2007) Embryonic and larval development of Haliotis tuberculata coccinea Reeve: an indexed micro-photographic sequence. Journal of Shellfish Research 26, 847-854.

Courtois de Viçose G., Viera M.P., Huchette S. and Izquierdo M.S. (2012) Larval settlement, early growth and survival of Haliotis tuberculata coccinea using several algal cues. Journal of Shellfish Research 31, 1189-1198.

Espino F. and Herrera R. (2002) Seguimiento de poblaciones de especies amenazadas 2002 (Haliotis tuberculata coccinea, Nordsieck, 1975) Gran Canaria. Final Report, 52 pp.

FAO (1995) Synopsis of biological data on the European abalone (Ormer) Haliotis tuberculata Linnaeus, 1758 (Gastropoda: Haliotidae). FAO Fisheries Synopsis no. 156, 36 pp.

Gruenthal K.M. and Burton R.S. (2005) Genetic diversity and species identification in the endangered white abalone (Haliotis sorenseni). Conservation Genetics 6, 929-939.

Gutierrez-Gonzalez J.L., Cruz P., del Rio-Portilla M.A. and Perez-Enriquez R. (2007) Genetic structure of green abalone Haliotis fulgens population off Baja California, Mexico. Journal of Shellfish Research 26, 839-846.

Guzmán del Próo S.A. (1992) A review of the biology of abalone and its fishery in Mexico. In Shepherd S.A., Tegner M.J. and Guzmán del Próo S.A. (eds) Abalone of the world: biology, fisheries and culture, Oxford: Blackwell, pp. 87-98.

Hackney C.R. and Rippen T.E. (2000) The molluscan shellfish industry. In Roy E.M., Paine Carter E., Flick G.J. and Lynn M.D. (eds) Marine and freshwater products handbook. Boca Raton, FL: CRC Press, pp. 323-324.

Huchette S.M.H. and Clavier J. (2004) Status of the ormer (Haliotis tuberculata L.) industry in Europe. Journal of Shellish Research 23, 951-955.

Kashiwada J.V. and Taniguchi I.K. (2007) Application of recent red abalone Haliotis rufescens surveys to management decisions outlined in the California Abalone Recovery and Management Plan. Journal of Shellfish Research 26, 713-717.

Leiva G.E. and Castilla J.C. (2001) A review of the world marine gastropod fishery: evolution of catches, management and the Chilean experience. Review of Fish Biology and Fisheries 11, 283-300.

Li Z.B., Appleyard S.A. and Elliott N.G. (2006) Population structure of Haliotis rubra from South Australia inferred from nuclear and mtDNA analyses. Acta Oceanologica Sinica 25, 99-112.

Maynard B.T., Hanna P.J. and Benzie J.A.H. (2004) Microsatellite DNA analysis of southeast Australian Haliotis laevigata (Donovan) populations - implications for ranching in Port Phillip Bay. Journal of Shellfish Research 23, 1195-1200.

McShane P.E. (1996) Patch dynamics and effects of exploitation on abalone (Haliotis iris) populations. Fisheries Research 25, 191-199.

Micheli F., Saenz-Arroyo A., Greenley A., Vazquez L., Espinoza Montes J.A., Rossetto M., and De Leo G.A. (2012) Evidence that marine reserves enhance resilience to climatic impacts. PLOS ONE 7, e40832.

Micheli F., Shelton A.O., Bushinsky S.M., Chiu A.L., Haupt A.J., Heiman K.W., Kappel C.V., Lynch M.C., Martone R.G., Dunbar R.B. and Watanabe J. (2008) Persistence of depleted abalones in marine reserves of central California. Biological Conservation 141, $1078-1090$.

Miller K.J., Maynard B.T. and Mundy C.N. (2009) Genetic diversity and gene flow in collapsed and healthy abalone fisheries. Molecular Ecology $18,200-211$.

Morales-Bojórquez E., Muciño-Díaz M.O. and Velez-Barajas J.A. (2008) Analysis of the decline of the abalone fishery (Haliotis fulgens and $H$. corrugata) along the west-central coast of Baja California Peninsula, Mexico. Journal of Shellfish Research 27, 865-870.

Nuñez J., Barquin J. and Brito A. (1994) Cartografía de la distribución, biología y evaluación de los recursos marisqueros de moluscos litorales canarios: lapas, orejas de mar y mejillón. $1^{a}$ fase. La Palma, Tenerife, Gran Canaria and Fuerteventura. Final Report, University of La Laguna, $323 \mathrm{pp}$.

Pascual-Fernandez J.J., Chinea-Mederos I. and De la Cruz-Modino R. (2015) Marine Protected Areas, small scale commercial versus recreational fishers: governability challenges in the Canary Islands. Spain. Interactive Governance for Small-Scale Fisheries 13, 397-412.

Riera R., Perez O., Alvarez O., Simon D., Diaz D., Monterroso O. and Nuñez J. (2016) Clear regression of harvested intertidal mollusks. A 20-year (1994-2014) comparative study. Marine Environmental Research 113, 56-61.

Rogers-Bennett L., Haaker P.L., Karpov K.A. and Kushner D.J. (2002) Using spatially explicit data to evaluate marine protected areas for abalone in southern California. Conservation Biology 16, 1308-1317.

Smil W. (2012) Harvesting the biosphere: what we have taken from nature. Cambridge, MA: MIT Press, $312 \mathrm{pp}$.

Tuya F., Boyra A., Sánchez-Jerez P., Barberá C. and Haroun R.J. (2004) Relationships between rocky-reef fish assemblages, the sea urchin Diadema antillarum and macroalgae throughout the Canarian Archipelago. Marine Ecology Progress Series 278, 157-169.

Underwood A.J. (1991) Beyond BACI: experimental designs for detecting human impacts on temporal variations in natural populations. Australian Journal of Marine and Freshwater Research 42, 569-687.

and

Viera M.P., Courtois de Viçose G., Fernandez-Palacios H. and Izquierdo M. (2016) Grow-out culture of abalone Haliotis tuberculata coccinea Reeve, fed land-based IMTA produced macroalgae, in a combined fish/abalone offshore mariculture system: effect of stocking density. Aquaculture Research 47, 71-81.

\section{Correspondence should be addressed to:}

R. Riera

Centro de Investigaciones Medioambientales del Atlántico, 38107 SC de Tenerife, Canary Islands, Spain email: rodrigo@cimacanarias.com 